University of Michigan Law School

University of Michigan Law School Scholarship Repository

\title{
Private Enforcement of Company Law and Securities Regulation in Korea
}

\author{
Hwa-Jin Kim \\ University of Michigan Law School, lbfk@umich.edu
}

Available at: https://repository.law.umich.edu/book_chapters/164

Follow this and additional works at: https://repository.law.umich.edu/book_chapters

Part of the Business Organizations Law Commons, Comparative and Foreign Law Commons, Legislation Commons, and the Securities Law Commons

\section{Publication Information \& Recommended Citation}

Kim, Hwa-Jin. "Private Enforcement of Company Law and Securities Regulation in Korea." In Enforcement of Corporate and Securities Law: China and the World, edited by Robin H. Huang and Nicholas C. Howson, 444-453. Cambridge: Cambridge University Press, 2017.

This Book Chapter is brought to you for free and open access by the Faculty Scholarship at University of Michigan Law School Scholarship Repository. It has been accepted for inclusion in Book Chapters by an authorized administrator of University of Michigan Law School Scholarship Repository. For more information, please contact mlaw.repository@umich.edu. 


\title{
Private Enforcement of Company Law and Securities Regulation in Korea
}

\author{
HWA-JIN KIM
}

\section{Introduction}

This chapter offers a brief overview of the private enforcement of corporate law and securities regulation in Korea, with particular reference to the current legislative efforts in the Korean National Assembly and recent court cases. This chapter also talks about Korea's ill-fated and misguided adoption of the fraud-on-the-market theory in securities fraud litigation.

\section{Private Enforcement of Corporate Law}

\subsection{Shareholder Derivative Suit}

The Korean Commercial Code (KCC) provides that where a director (1) has acted in violation of any laws and regulations or in violation of the company's articles of incorporation or (2) has neglected to perform his or her duties, such director shall be jointly and severally liable for damages to the company resulting from such acts or omissions. ${ }^{1}$ This rule is privately enforced through the shareholders derivative litigation under Articles 403, 404, 405 and 406 of the KCC.

The shareholders derivative suit mechanism has been in place since the enactment of the KCC in 1960. However, up until 1997, for the thirty-five years since the enactment, not a single lawsuit was filed. After the Asian

1 Art. 399 Para. 1 KCC. The director's basic duty of care is provided in Art. 382 Para. 2 KCC that refers to Art. 681 (fiduciary duty in the agency relationship) Korean Civil Code. In practice, the duty of care shall require the directors of the following actions: duty of attention on the activities of the company; duty to attend meetings; duty to review corporate information and documents; duty to thoroughly discuss major policies and business issues; and duty to review all major filings with the regulatory agencies. See generally Hwa-Jin Kim and Sung-Joon Park, 'Directors' Duties and Liabilities in Korean Companies', in Korean Business Law, Hwa-Jin Kim ed., (Edward Elgar, 2012), 1. 
economic crisis in 1997, some shareholder activist groups started to use the derivative litigation to improve corporate governance of large Korean companies. ${ }^{2}$ Still, the genuine derivative suits are rare. Ordinary shareholders hardly have incentives to file the suit. Private enforcement of corporate law in Korea is more to improve corporate governance of Korean firms than for legal remedy. For that reason, current policy discussion focuses rather on the introduction of double derivative lawsuit.

\subsection{Double Derivative Suit}

The discrepancy between cash-flow right and control right in big Korean conglomerates (Chaebols) is quite substantial. For instance, the average ownership of the controlling shareholders of non-public member firms of Samsung Group was 78.43 per cent, whereas their cash-flow rights were as low as 19.43 per cent. ${ }^{3}$ For public member firms the number was 13.52 per cent and 1.14 per cent, respectively. ${ }^{4}$ Since Korea does not allow dual-class commons, the discrepancy comes from control over affiliated firms, including financial firms, and circular shareholdings. Those affiliated firms are quite often non-listed private firms that are not subject to the disclosure obligations of the Korean Capital Markets Act (KCMA). In such a complicated ownership structure with a lack of transparency, there is a risk that non-listed subsidiaries may be used for tunneling and other questionable rent-seeking acts. Even if something were to happen at the subsidiary level, the only shareholder is the parent controlled by the controlling minority shareholder. He or she won't cause the firm to sue managers of subsidiaries. Reformist groups are trying to rectify the situation through introducing the double derivative lawsuit into the KCC.

Surprisingly, in 2003, the Seoul High Court ruled that shareholders of a listed company can sue the directors of non-listed subsidiaries. ${ }^{5}$ The case involved a manager of an 80 per cent subsidiary who committed embezzlement. The court pointed out the possibility and risk of

${ }^{2}$ See Bernard Black, Brian Cheffins and Michael Klausner, 'Shareholder Suits Against Korean Directors', in Korean Business Law, Hwa-Jin Kim ed. (Edward Elgar, 2012), 27, $35-40$.

${ }^{3}$ For the corporate governance issues of Samsung Group, see Hwa-Jin Kim, 'Concentrated Ownership and Corporate Control: Wallenberg Sphere and Samsung Group', 14 Journal of Korean Law 39 (2014).

${ }^{4}$ See James Jinho Chang and Hyun-Han Shin, 'Family Ownership and Performance in Korean Conglomerates', 15 Pacific-Basin Finance Journal 329 (2007).

5 Judgment of 22 August 2003, 2002-Na-13746. 
wrongdoings through subsidiaries under common control of the managers of the listed parent. The court also opined that the definition of the shareholder under Article 403 of the KCC shall include the shareholder of the parent company. ${ }^{6}$ However, the Korean Supreme Court quickly reversed the decision of the Seoul High Court in 2004 by ruling that the shareholder of the listed parent company does not qualify as the shareholder of its subsidiaries. ${ }^{7}$

The case reignited the policy discussion, and a revision of the KCC has been the subject of a lively debate since then. Finally in 2013, the Korean Ministry of Justice submitted a bill to the Korean National Assembly which included, among others, the double derivative lawsuit. However, the controversial bill did not go through the final stage of the legislative procedure and is still pending. The Korean National Assembly is currently discussing ways to reform the corporate governance of large conglomerates. The double derivative lawsuit is very much on the agenda of the relevant committees of the legislative body.

The concern is that private companies may more or less become public companies through strike lawsuits, thus losing the privilege and benefit of being private. ${ }^{8}$ When introduced, if at all, the court shall take a conservative approach to the double derivative suit. The judgment of the Seoul High Court was based on the compensation and deterrence theory. ${ }^{9}$ In this particular case, veil piercing was not available because there existed no 100 per cent relationship between the parent and the subsidiary. It should be noted, however, that in the United States most court cases adopt the veil piercing theory in allowing a double derivative suit. ${ }^{10}$ As Korean case law is already familiar with veil piercing, ${ }^{11}$ the double derivative suit may not be that necessary after all.

${ }^{6}$ See Ok-Rial Song, 'The Double Derivative Suits under the Commercial Code', 28 Korean Civil Law Case Studies 528 (2006) (Kor.) (supporting the judgment).

${ }^{7}$ Judgment of 23 September 2004, 2003-Da-49221.

8 There is a report that from 2000 to 2004,81 per cent of the lawsuits filed against business corporations were dismissed or withdrawn. See Hwa-Jin Kim, Corporate Finance and Governance, 2nd ed., (Pakyoungsa, 2012) (Kor.), 304.

9 There are scholarly opinions that the shareholder derivative lawsuit does not deter wrongdoings of corporate managers, see, e.g. Roberta Romano, 'The Shareholder Suit: Litigation without Foundation?', 7 Journal of Law, Economics, and Organization 55 (1991).

10 See David W. Locascio, 'The Dilemma of Double Derivative Suits', 83 Northwestern University Law Review 729 (1989), 743-746.

11 See, e.g. the Korean Supreme Court Judgment of 19 January 2001, 97-Da-21604. See generally Joseph Cho and Eun Young Shin, 'Piercing of the Corporate Veil in Korea: Case Commentary', Korean Business Law, Hwa-Jin Kim ed. (Edward Elgar, 2012), 101. 


\section{Private Enforcement of Securities Regulation}

\subsection{Securities Fraud Litigation}

With respect to public companies in Korea, any director who provides false or misleading statements or fails to indicate material concerns shall be liable to the party for any damages incurred as a result of such false statements or material omissions. They have a due diligence defence. ${ }^{12}$ This rule applies to frauds in the primary as well as secondary markets, and has been well enforced privately, creating sizable case law and professional literature. ${ }^{13}$ Therefore, in terms of the private enforcement of securities regulation in Korea, the 'new' securities class action has received more attention.

\subsection{Securities Class Action}

The controversial Securities Class Action Act (SCAA) was passed by the Korean National Assembly in December of 2003 with the aim of providing a more effective means of relief for small investors in the capital markets while at the same time enhancing the transparency of corporate governance. The SCAA came into full effect on 1 January 2007. The cause of action is narrower than which is available in the United States. Claims for damages under the SCAA are limited to the recovery of loss arising from false statements in the registration statements, business prospectuses, annual, semi-annual and quarterly reports, insider trading, stock price manipulation, and faulty auditing.

The first class action lawsuit was filed in April of 2009. The second and third lawsuits were filed in December of 2011 and in June of 2014, respectively. Only nine lawsuits have been filed in the past ten years. In other words, it looks like the law has become almost ineffectual. It should be noted though that the law went into effect in 2007, i.e. after a three-year waiting period. When the law was enacted, Korean firms were understandably horrified and substantially improved accounting practices during those three years. The law stipulated that if firms confess past sins, it won't be applied retroactively. ${ }^{14}$ In that sense, the law contributed to the improvement of corporate governance of large Korean firms.

12 Art. 125 and Art. 162 of the KCMA. These provisions will be discussed below.

13 See Hwa-Jin Kim, Theoretical Foundations of Securities Regulation, (Pakyoungsa, 2004), Ch. 3.(Kor.).

${ }^{14}$ See Kim, Corporate Finance and Governance, 349. 
Unfortunately, the future of the SCAA does not look bright. There is no Milberg (Weiss) in Korea. Furthermore, no contingency fee arrangement is allowed. ${ }^{15}$ Since no discovery is available in civil procedure, plaintiffs regularly have a hard time proving the claim despite the fact that Korean law is quite accommodating, as discussed below. In addition, no institutional investor may want to play the lead plaintiff due to their relationships with potential fee-paying corporate clients. ${ }^{16}$ Perhaps the introduction of the securities class action in Korea will remain and be recorded as too hasty and ambitious a reform effort.

\section{Halliburton in Korea?}

\subsection{Importing the Fraud-on-the-Market}

As far as the securities fraud action is concerned, Korea imported all the elements of the cause of action from the United States except scienter: Materiality, misrepresentation or omission, reliance, causation and damages. ${ }^{17}$ Korean law does not know the concept of scienter. The focus here is on reliance, which is the single most controversial requirement in securities fraud litigation in Korea, and any jurisdiction for that matter.

Basic Inc. v. Levinson ${ }^{18}$ introduced the rebuttable presumption of reliance in securities fraud litigation (transaction causation requirement) based on the fraud-on-the-market theory. ${ }^{19}$ However, the US Federal

15 See Black, Cheffins and Klausner, 'Shareholder Suits Against Korean Directors', at 42. The SCAA provides for attorney's fees to be paid out of the recovery to the plaintiff class. Art. 44 of the SCAA.

${ }^{16}$ Cf. Ronald J. Gilson and Jeffrey N. Gordon, 'The Agency Costs of Agency Capitalism: Activist Investors and the Reevaluation of Governance Rights', 113 Columbia Law Review 863 (2013).

17 For cause of action, see generally James D. Cox, Robert W. Hillman and Donald C. Langevoort, Securities Regulation: Cases and Materials, 7th ed., (Wolters Kluwer, 2013) Chs.9 and 13.

18485 U.S. 224 (1988). See Donald Langevoort, 'Basic at Twenty: Rethinking Fraud on the Market', Wisconsin Law Review 157 (2009); Jonathan R. Macey et al., 'Lessons from Financial Economics: Materiality, Reliance, and Extending the Reach of Basic v. Levinson', 77 Virginia Law Review 1017 (1991).

19 Cf. Note, 'The Fraud-on-the-Market Theory', 95 Harvard Law Review 1143 (1982); Brad M. Barber et al., 'The Fraud-on-the-Market Theory and the Indicators of Common Stocks' Efficiency', 19 Journal of Corporation Law 285 (1994); Daniel R. Fischel, 'Use of Modern Finance Theory in Securities Fraud Cases Involving Actively Traded Securities', 38 Business Lawyer 1 (1982); Jonathan R. Macey and Geoffrey P. Miller, 'Good Finance, Bad Economics: An Analysis of the Fraud-on-the-Market Theory', 42 Stanford Law Review 1059 (1990); Jonathan R. Macey, 'The Fraud-on-theMarket Theory: Some Preliminary Issues', 74 Cornell Law Review 923 (1989). For the 
Supreme Court decision has been very controversial. For example, some voices were raised to reconsider the case in Amgen Inc. et al. v. Connecticut Retirement Plans and Trust Funds. ${ }^{20}$ And, in 2014, it once again became the hot issue in Halliburton Co. et al. v. Erica P. John Fund, Inc. (23 June 2014). ${ }^{21}$ Although Halliburton did not change precedent, it seemed evident that the fraud-on-the-market theory was still facing tough challenges from new perspectives in contemporary economics. $^{22}$

Halliburton was a wake-up call whereas Basic was an inspiration for the Korean legislature and judiciary. The Korean Supreme Court adopted the fraud-on-the-market theory not only in the securities fraud litigation, but also in litigations in tort law claims. It is interesting to note that under the KCMA there is no transaction causation requirement at all.

Article 125 (Liabilities for Damages Caused by False Statements, etc.)

(1) The following persons shall be liable for damages inflicted upon any person as a result of acquiring securities by including a false description or representation of any material fact in a registration statement (including a corrective registration statement and supplements thereto; hereafter the same shall apply in this Article) and an investment prospectus (including a preliminary investment prospectus and a short-form investment prospectus; hereafter the same shall apply in this Article) or omitting a material fact therefrom: Provided, that such person shall not be liable if he/she proves that he/she was unable to discover such inclusion or omission even if he/she exercised reasonable care or that the person who acquired the securities knew the fact at the time when he/she made an offer to acquire them: ...

\section{Article 162 (Liability for Damages Caused by False Description, etc.)}

(1) The following persons shall be liable for damages sustained by a person who acquired or disposed of securities (including securities depositary

Efficient Capital Market Hypothesis, see Ronald Gilson and Reinier Kraakman, 'The Mechanisms of Market Efficiency', 70 Virginia Law Review 549 (1984); Donald Langevoort, 'Theories, Assumptions, and Securities Regulation: Market Efficiency Revisited', 140 University of Pennsylvania Law Review 851 (1992); Reinier Kraakman, 'Taking Discounts Seriously: The Implications of 'Discounted' Share Prices as an Acquisition Motive', 88 Columbia Law Review 891 (1988).

${ }^{20} 133$ S. Ct. 1184 (2013). See Donald C. Langevoort, 'Judgment Day for Fraud-on-theMarket?: Reflections on Amgen and the Second Coming of Halliburton', Georgetown Public Law and Legal Theory Research Paper No. 13-058 (2013).

${ }^{21}$ See Lucian A. Bebchuk and Allen Ferrell, 'Rethinking Basic', 69 Business Lawyer 671 (2014); Merritt B. Fox, 'Halliburton II: What It's All About', 1 Journal of Financial Regulation 135 (2015).

${ }^{22}$ Cf. Cass R. Sunstein et al., 'A Behavioral Approach to Law and Economics', 50 Stanford Law Review 1471 (1998); Ryan Bubb and Richard H. Pildes, 'How Behavioral Economics Trims Its Sails and Why', 127 Harvard Law Review 1593 (2014). 
receipts related to such securities and other securities specified by Presidential Decree; hereafter the same shall apply in this Article) issued by a corporation obligated to submit a business report due to a false description or representation of a material fact in such business report, half-yearly report, quarterly report, or material fact report under Article 159 (1) (hereinafter referred to as 'business report, etc.') or a document attached thereto (excluding audit reports prepared by an accounting auditor), or due to an omission of a description or representation of a material fact therein: Provided, That a person held liable for such damages shall not be liable if he/she proves that he/she was unable to know such fact although he/she exercised reasonable care, or that the person who acquired or disposed of such securities knew the fact at the time he/she acquired or disposed of the securities ...

The Korean Supreme Court adopted the fraud-on-the-market theory in a more plaintiffs-friendly way because of the statutes' wording. Reliance is not even presumed; it is given. As a result, it cannot be rebutted. ${ }^{23}$ The provisions in the KCMA were not a drafting error of some sort. It was the 1997 financial crisis, which created a scenario last observed in the 1930s in the United States. Plaintiffs had to be strongly protected at that time. As there was no discovery available in Korea, this was how the country decided to respond. The Korean Supreme Court went one step further in that it adopted the fraud-on-the-market theory even in tort law cases, ${ }^{24}$ whereas the US state courts never adopted the fraud-on-the-market theory in such cases. ${ }^{25}$

\subsection{Comparison: German Law}

In Germany, only ad hoc disclosures are regulated by the German Securities Exchange Act (Gesetz über den Wertpapierhandel - WpHG) whereas fraud through periodic disclosures is regulated by tort law, i.e. the German Civil Code (Bürgerliches Gesetzbuch: BGB). Registration statements are regulated by other statutes. ${ }^{26}$ To be sure, fraud in the

23 Judgment of 25 October 2007, 2006-Da-16758, 16765; Judgment of 11 October 2002, 2002-Da-38521.

24 Judgment of 12 September 1997, 96-Da-41991; Judgment of 28 January 2010, 2007-Da16007.

${ }^{25}$ Cf. Mirkin v. Wasserman, 23 Cal. Rptr. 2d 101, 858 P.2d 568 (Cal. 1993). See Christopher Boffey, 'Mirkin v. Wasserman: The Supreme Court of California Rejects the Fraud-on-the-Market Theory in State Law Deceit Actions', 49 Business Lawyer 715 (1994).

26 Registration statements are regulated by Verkaufsprospektgesetz and Börsengesetz. See Barbara Grunewald and Michael Schlitt, Einführung in das Kapitalmarktrecht 235-261 (3.Aufl., C.H.Beck, 2014). 
primary market and fraud by ad hoc disclosure can also be actionable by tort law and a sizable body of case law has been developed. ${ }^{27}$

Even though Germany has actively imported many principles and case law in corporate law and securities regulation, ${ }^{28}$ the German law and Federal Supreme Court (Bundesgerichtshof: BGH) explicitly reject the fraud-on-the-market theory. ${ }^{29}$ Fraudulent $a d$ hoc disclosure is regulated by Articles 37b (material omission) and 37c (misrepresentation) of the WpHG. Article $37 \mathrm{c}$ requires the reliance element by stipulating that the plaintiff shall have trusted the misrepresentation. In terms of Article 37b, the transaction causation exists through the proposition that without the material omission, the plaintiff would not have purchased the securities. ${ }^{30}$ These Articles also require loss causation as an element of the cause of action. ${ }^{31}$ The burden of proof on causation lies on the plaintiff. ${ }^{32}$

German courts treat securities fraud litigations almost like general tort law litigations. ${ }^{33}$ This is partly because frauds in the primary markets are regulated only by the BGB. The German Federal Court once directly referred to the 'fraud-on-the-market theory in the US securities regulation' and rejected an adoption of the theory in fraudulent ad hoc disclosure cases in that such an adoption would expand the scope of liabilities under Article 826 of the BGB too far. ${ }^{34}$

27 For the German law of securities fraud, see generally, Alexander Hellgardt, Kapitalmarktdeliktsrecht (Mohr Siebeck, 2008); Stefan Richter, Schadenszurechnung bei deliktischer Haftung für fehlerhafte Sekundärmarktinformation (Mohr Siebeck, 2012). For other European jurisdictions, see Klaus J Hopt and Hans Ch. Voigt (Hrsg.), Prospekt- und Kapitalmarktinformationshaftung: Recht und Reform in der Europäischen Union, der Schweiz und den USA (C.H.Beck, 2004).

${ }^{28}$ See Jan von Hein, Die Rezeption US-amerikanischen Gesellschaftsrechts in Deutschland (Mohr Siebeck, 2008).

29 See Kim, Theoretical Foundations of Securities Regulation, 88-92.

30 Peter O. Mülbert and Steffen Steup, 'Haftung für fehlerhafte Kapitalmarktinformation', in Mathias Habersack et al. (Hrsg.), Unternehmensfinanzierung am Kapitalmarkt 915, 985 (2. Aufl., DrOttoSchmidt, 2008).

31 Mülbert and Steup, 'Haftung für fehlerhafte Kapitalmarktinformation', 986; Grunewald and Schlitt, Einführung in das Kapitalmarktrecht, 288.

32 Mülbert and Steup, 'Haftung für fehlerhafte Kapitalmarktinformation', 987; Grunewald and Schlitt, Einführung in das Kapitalmarktrecht, 288.

33 See BGH 28.11.2005 - II ZR 80/04, NZG 2007, 345, 346: BGH 4.6.2007, ZIP 2007, 1560, 1562.

34 BGH, Beschluss vom 26. Juni 2006 - II ZR 153/05; BGH, WM 2007, 1557, 1559 (ComROAD Case). Art. 826 of BGB applies to frauds in the secondary markets. Richter, supra note $27,82-83$. To be actionable under Art. 826 of BGB, the transaction causation between defendant's misrepresentation and plaintiff's investment decision. Mülbert and Steup, 'Haftung für fehlerhafte Kapitalmarktinformation', 992. 
In addition to the conventional developments in tort law, German academia and some court decisions have been referring to the concept of 'Investment Atmosphere' (Anlagestimmung). According to this line of scholarly opinion and cases, the investors are presumed to have relied on misrepresentation when the investor made an investment decision based on an inflated investment atmosphere created by an investment prospectus or memorandum. ${ }^{35}$ This is reminiscent of Basic. There have been discussions in Germany on a possible expansion of the concept to strengthen the liabilities out of misrepresentation in the capital markets. The discussion was obviously influenced by the Efficient Capital Market Hypothesis. ${ }^{36}$ However, the German Federal Supreme Court rejected the concept. According to the Court, an investment decision depends upon building of intent on an individual level to which many reasonable and unreasonable factors contribute. Those factors cannot be easily generalised. ${ }^{37}$ Many commentators support the Federal Supreme Court's rejection of the Anlagestimmung. ${ }^{38}$

\subsection{A New Perspective}

Now is the time to reconsider the whole thing. Circumstances have significantly changed since 1997 . Investor protection mechanisms are relatively well in place in the Korean capital markets. Financial regulation and supervision work reasonably well. ${ }^{39}$ Korea also needs a strong and sound securities industry. The ultimate purpose of the KCMA has not received the attention it needs. The primary purpose of the securities regulation is the protection of investors. There is no debate about that. But, the scope of the KCMA is much broader as its Article 1 stipulates.

The burden of proof is on the plaintiff. Ibid., at 993. Plaintiff must prove that the particular misrepresentation did constitute the core element of plaintiff's investment decision. Richter, Schadenszurechnung, at 88.

35 OLG Frankfurt a.M., WM 1994, 291, 198; OLG Frankfurt a.M., WM 1996, 1216, 1219.

36 See, e.g. Theodor Baums, 'Haftung wegen Falschinformation des Sekundärmarkts', 167 Zeitschrift für das gesamte Handelsrecht und Wirtschaftsrecht 139 (2003); Knut Sauer, 'Kausalität und Schaden bei der Haftung für falsche Kapitalmarktinformationen', Zeitschrift für Bankrecht und Bankwirtschaft 24 (2005).

37 Richter, Schadenszurechnung, 89-92.

${ }^{38}$ Matthias Casper, 'The Significance of the Law of Tort with the Example of the Civil Liability for Erroneous ad hoc Disclosure', in Reiner Schulze ed., Compensation of Private Losses, (De Gruyter, 2011) 91, 98; Richter, Schadenszurechnung, 91.

39 Cf. Hwa-Jin Kim, 'Financial Regulation and Supervision in Corporate Governance of Banks', 41 Journal of Corporation Law 707 (2016). 


\section{Article 1 (Purposes)}

The purpose of this Act is to contribute to the development of the national economy by facilitating financial innovation and fair competition in the capital market, protecting investors, fostering the development of the financial investment business, and heightening the fairness, reliability, and efficiency of the capital market.

The Korean Supreme Court's adoption of the fraud-on-the-market theory in its current fashion must be changed. The KCMA should also, at the very least, adopt Basic, i.e. the reliance requirement of the cause of action must be added as German statute has already done. On a separate note, there have been academic voices that express concern over the trend that securities law is becoming a little too much like consumer protection law. ${ }^{40}$ Balance is needed.

Korea has adopted many things from the United States law, including the squeeze-out merger, ${ }^{41}$ the corporate opportunity doctrine ${ }^{42}$ and securities class action. Others are waiting in line, such as the poison pill and the dual-class commons. Unfortunately, some are misguided and ill fated. The fraud-on-the-market theory in the KCMA in its current form and tort law cases is the most conspicuous example.

40

Cf. Zohar Goshen and Gideon Parchomovsky, 'The Essential Role of Securities Regulation', 55 Duke Law Journal 711 (2006), 713; Jeffrey N. Gordon and Lewis A. Kornhauser, 'Efficient Markets, Costly Information, and Securities Research', 60 New York University Law Review 761(1985), 802. See also the German literature Grunewald and Schlitt, Einführung in das Kapitalmarktrecht, at 3; Petra Buck-Heeb, Kapitalmarktrecht 3-7 (6.Aufl., C.F.Müller, 2013).

${ }^{41}$ See Hyeok-Joon Rho, 'New Squeeze-Out Devices as a Part of Corporate Law Reform in Korea', in Korean Business Law, Hwa-Jin Kim ed., (Edward Elgar, 2012), 52.

${ }^{42}$ See Hwa-Jin Kim, Seung-Hwan Lee and Stephen Woodcock, 'Favoritism and Corporate Law: The Confused Corporate Opportunity Doctrine in the Hyundai Motor Case', 3 Michigan Journal of Private Equity and Venture Capital Law 41 (2013). 